\title{
THE SLIDING VELOCITY OF ATHABASGA GLACIER, CANAdA
}

\author{
By W. S. B. Paterson \\ (Polar Continental Shelf Project, Department of Energy, Mines and Resources, Ottawa, \\ Ontario, Canada)
}

\begin{abstract}
A method of estimating sliding velocity is presented. It rests on few assumptions, one of which is that longitudinal strain-rate varies linearly with depth. The flow law of ice is not used. To apply it, the sliding velocity at one point must be known. The method is used to calculate the sliding velocity at twelve points on Athabasca Glacier. These values are not related to calculated basal shear stresses. Thus one or more of the following statements must be true: ( 1 ) basal shear stress cannot be calculated by the conventional formula, (2) the roughness of the glacier bed varies from place to place, (3) sliding velocity does not obey Weertman's formula. Analysis of seven published measurements of sliding velocity leads to the same conclusion.
\end{abstract}

Résumé. La vitesse de glissement de l'Athabasca Glacier. Une methode d'estimation de la vitesse de glissement est presentée. Elle repose sur quelques hypothèses dont l'une est que la vitesse de deformation longitudinale varie linéairement avec le profondeur. Elle n'utilise pas la loi d'ecoulement de la glace. Pour l'appliquer, la vitesse de glissement en un point doit être connue. La methode est utilisée pour calculer la vitesse de glissement en I 2 points de l'Athabasca Glacier. Ces valeurs ne sont pas liées aux contraintes de cisaillement basales calculés. Ainsi un ou plusieurs des sentences suivantes doivent être exactes: (I) la contrainte de cisaillement basale ne peut être calculée par la formule classique, (2) la rugosité du lit du glacier varie d'un endroit à l'autre, (3) la vitesse de glissement n'obéit pas à la formule de Weertman. L'analyse de sept mesures publiées de la vitesse de glissement mène à la même conclusion.

Zusammenfassung. Die Gleitgeschwindigkeit des Athabasca Glacier. Es wird eine Methode zur Abschätzung der Gleitgeschwindigkeit vorgelegt. Sie beruht auf wenigen Annahmen, von denen eine die ist, dass die longitudinale Deformationsgeschwindigkeit sich linear mit der Tiefe ändert; sie benutzt nicht das Fliessgesetz des Eises. Für ihre Anwendung muss die Gleitgeschwindigkeit an einem Punkt bekannt sein. Die Methode wird zur Berechnung der Gleitgeschwindigkeit an zwölf Punkten des Athabasca Glacier verwendet. Diese Werte stehen in keinem Zusammenhang mit berechneten Scherspannungen am Grund. Deshalb muss mindestens eine der folgenden Feststellungen zutreffen: ( I) Die Scherspannung am Grund kann nicht mit der konventionellen Formel berechnet werden; (2) die Rauhigkeit des Gletscherbettes ändert sich von Ort zu Ort; (3) die Gleitgeschwindigkeit erfüllt nicht Weertman's Formel. Die Analyse von sieben veröffentlichten Messungen der Gleitgeschwindigkeit führt zu demselben Schluss.

\section{Introduction}

The mechanism by which a temperate glacier slides over its bed is a topic of considerable interest, and some controversy, at present. To date, theoretical studies have predominated; Lliboutry ( 1968 ) has listed most of the relevant papers. To measure the sliding velocity of a glacier is difficult. The usual approach is to calculate its value from measurements of surface velocity by the formula (Nye, 1952):

$$
u_{\mathrm{b}}=u_{\mathrm{s}}-A \tau^{n} h /(n+\mathrm{I}) .
$$

Here $u_{\mathrm{b}}$ is sliding velocity, $u_{\mathrm{s}}$ velocity at the surface, $h$ ice thickness, and $A$ and $n$ are parameters in the flow law of ice. The basal shear stress $\tau$ is given by

$$
\tau=F \rho g h \sin \alpha
$$

where $\rho$ is the density of ice, $g$ the acceleration due to gravity, $\alpha$ the surface slope, and $F$ is a "shape factor" introduced to allow in an approximate way for the effect of the valley walls.

Nye (1952) pointed out several reasons why this method of calculating $u_{\mathrm{b}}$ is not very reliable: the underlying assumption, that the longitudinal strain-rate in the glacier is zero, may be false; the calculated value of $\tau$ may not be equal to the actual shear stress; the values of $A$ and $n$ are not precisely known for the type of ice in the glacier in question. Thus an alternative method of calculation may be useful.

The sliding velocity of Athabasca Glacier has been determined at two points where bore holes reached the glacier bed (Savage and Paterson, 1963). We have devised a method of estimating, by extrapolation from these measured values, the sliding velocity at twelve other 
points where ice thickness and other parameters have been measured. This method rests on few assumptions and, in particular, does not use the flow law of ice. In this paper we describe the method and discuss how the resulting values of sliding velocity are related to basal shear stress and other parameters.

\section{Athabasca Glacier}

Athabasca Glacier (lat. $52.2^{\circ}$ N., long. $117.2^{\circ} \mathrm{W}$.) is one of the main outlet glaciers from the Columbia Icefield in the Canadian Rocky Mountains. The glacier descends from the Icefield in a series of three ice falls over a distance of $2 \mathrm{~km}$. The measurements to be discussed were made in the section between the foot of the lowest ice fall and the terminus. The length of this section is $3.8 \mathrm{~km}$, its average width $1.1 \mathrm{~km}$. The width varies only slightly, and the only bend is a slight one about $\mathrm{I} \mathrm{km}$ from the terminus. The surface slope, generally between $2^{\circ}$ and $6^{\circ}$, increases to about $20^{\circ}$ at the terminus. The maximum ice thickness is about $325 \mathrm{~m}$. This section of the glacier is virtually free of crevasses except near its sides and in two small areas, one immediately above the terminus and one about $1.5 \mathrm{~km}$ from it. Ice velocity decreases from about $75 \mathrm{~m} \mathrm{a}^{-1}$ just below the lowest ice fall to about $10 \mathrm{~m} \mathrm{a}{ }^{-1}$ near the terminus.

\section{Measurements}

We shall mention briefly how we measured those parameters used in the subsequent analysis. Readers who want further details are referred to previous papers (Paterson and Savage, r963[a]; Savage and Paterson, r963).

\section{Surface slope}

The surface slope, averaged over a distance comparable with the ice thickness, was measured from a map of the glacier at scale $\mathrm{I}: 4800$ with $\mathrm{Io} \mathrm{ft}(3.048 \mathrm{~m})$ contours. The standard error of each measurement is estimated to be $0.3^{\circ}$.

\section{Ice thickness}

Ice thickness was determined by seismic sounding at 15 points along the center-line of the glacier. The standard error of each measurement is about $5 \mathrm{~m}$.

\section{Bed slope}

The slope of the glacier bed at each seismic station was calculated from the move-out of a reflection trough across the twelve traces of a single reflection record. This is an accurate method of determining the average slope over the distance covered by the geophone spread (about $100 \mathrm{~m}$ ). Thus the measurements of bed slope at each station are independent of the

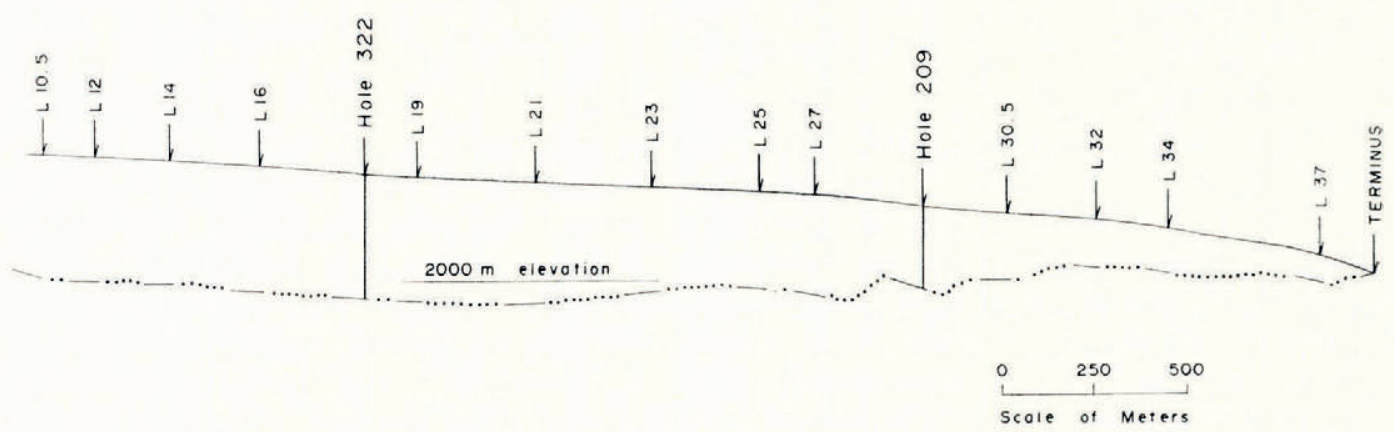

Fig. I. Cross-section of the lower part of Athabasca Glacier, along the center-line, with seismic stations. Recorded reflection surfaces are shown as heavy line segments; bore holes as vertical lines. There is no vertical exaggeration in scale. 
measurements of ice thickness. The standard error of a measurement of bed slope is estimated to be $20 \%$.

The average slope of the bed between adjacent stations, also needed in the analysis, was determined from the difference in elevation of the bed between the two stations. The elevation of the bed was calculated from ice thickness and surface elevation.

Figure I shows the profile of the glacier along the center-line and the locations of seismic stations and bore holes. (Seismic measurements were made at the bore holes.)

\section{Surface velocity}

Horizontal and vertical components of surface velocity, with respect to axes fixed in space, were determined by conventional survey methods. Velocities were measured at $3^{\circ}$ stakes along the center-line (these included the seismic stations), and at 6 to ro stakes in each of 6 transverse lines. Both components were measured with an estimated standard error of 0.15 $\mathrm{m} \mathrm{a}^{-1}$.

\section{Sliding velocity}

Sliding velocity was determined from the surface velocity combined with inclinometer measurements in two bore holes that penetrated to the glacier bed. The bore holes, holes 322 and 209 , are designated by their depth in meters. Hole 322 was surveyed in r96o and r $96 \mathrm{r}$. The velocity at a depth of $316 \mathrm{~m}$, the lowest point at which inclination was measured, was $32.0 \mathrm{~m} \mathrm{a}^{-1}$. Extrapolation of the velocity curve to the base of the ice gives a sliding velocity of $30 \mathrm{~m} \mathrm{a}^{-1}$. Hole 209 was surveyed in 1960 , $196 \mathrm{I}$ and $\mathrm{I} 962$. The velocity was $9.2 \mathrm{~m} \mathrm{a}^{-1}$ at $196 \mathrm{~m}$ for $1960-6 \mathrm{r}$ and $16.6 \mathrm{~m} \mathrm{a}^{-1}$ at $192 \mathrm{~m}$ for $196 \mathrm{r}-62$. Extrapolation to the base of the ice gives sliding velocities of $3 \mathrm{~m} \mathrm{a}^{-1}$ for $1960-6 \mathrm{r}$ and $\mathrm{ro} \mathrm{m} \mathrm{a}^{-1}$ for $\mathrm{r} 96 \mathrm{r}-62$. We take an average value of $6.5 \pm 3.5 \mathrm{~m} \mathrm{a}^{-1}$.

\section{Surface strain-rate}

At the bore holes, the longitudinal and transverse surface strain-rates were determined by means of four stakes arranged in a diamond pattern. The length of each side of the diamond was roughly equal to the ice thickness. Lengths were measured by steel tape. The standard error of these strain-rates is about $0.001 \mathrm{a}^{-1}$.

In addition, the longitudinal strain-rate between each pair of adjacent stakes on the center-line was calculated from the survey data. Similarly the transverse strain-rate was measured between the center stakes on each transverse line. The standard error of these strain-rates is $0.002 \mathrm{a}^{-1}$.

The transverse strain-rate, at points where it was not measured, was determined by interpolation. An alternative method would have been to calculate the strain-rate from the way in which the glacier's width varies along its length. However, this method gives the transverse strain-rate averaged over the glacier's width. Because the strain-rate in the vicinity of the center-line, required in the present analysis, may well be less than the average strainrate, we preferred to interpolate between measured values.

\section{Estimation Of SLiding velocity}

The method consists of calculating $\left(\dot{\epsilon}_{x}\right)_{\mathbf{b}}$, the longitudinal strain-rate at the glacier bed. Then, if we start at a point where the sliding velocity $u_{\mathrm{b}}$ is known, we can calculate $u_{\mathrm{b}}$ at the next seismic station, and so on.

We have already shown that, in Athabasca Glacier, the longitudinal strain-rate varies with depth (Paterson, unpublished; Paterson and Savage, r963 [b], Savage and Paterson, 1963). Our method consisted of calculating $\overline{\dot{\epsilon}}_{x}$, the strain-rate averaged over the ice thickness, and showing that it differed significantly from $\left(\dot{\epsilon}_{x}\right)_{\mathrm{s}}$, the strain-rate measured at the surface. Raymond and Kamb ( 1968 ) have subsequently confirmed this conclusion by measurements 
in several bore holes in the vicinity of our hole 322 . That we cannot use $\left(\dot{\epsilon}_{x}\right)_{\mathrm{s}}$ to extrapolate a measured value of $u_{\mathrm{b}}$ to other points is obvious from the following fact: the sliding velocity at hole 209 is about $23.5 \mathrm{~m} \mathrm{a}^{-1}$ less than that at hole 322 ; the difference in surface velocity is only io $\mathrm{m} \mathrm{a}^{-1}$.

We use a coordinate system fixed in space. The origin is below the glacier bed. The $x$-axis is horizontal, in the direction of flow along the center-line (assumed straight), positive in the direction of flow. The $y$-axis is vertical, positive upwards. The $z$-axis is chosen to make the system right-handed. The corresponding velocity components are $u, v, w$. Strain-rates are denoted by $\dot{\epsilon}_{x}, \dot{\epsilon}_{y}, \dot{\epsilon}_{z}$, and time by $t$. The glacier surface is

$$
F_{\mathrm{s}}(x, y, z, t)=y-h_{\mathrm{s}}(x, z, t)=0,
$$

and the glacier bed is

$$
F_{\mathrm{b}}(x, y, z)=y-h_{\mathrm{b}}(x, z)=\mathrm{o},
$$

where $h_{\mathrm{s}}, h_{\mathrm{b}}$ are arbitrary functions.

Because ice is incompressible, we have

Thus

$$
\begin{gathered}
\dot{\boldsymbol{\epsilon}}_{x}+\dot{\boldsymbol{\epsilon}}_{y}+\dot{\boldsymbol{\epsilon}}_{z}=0 . \\
-\hat{\partial} v / \partial y=-\dot{\boldsymbol{\epsilon}}_{y}=\dot{\boldsymbol{\epsilon}}_{x}+\dot{\boldsymbol{\epsilon}}_{z} .
\end{gathered}
$$

Integration with respect to $y$, between the limits $h_{\mathrm{b}}$ and $h_{\mathrm{s}}$, gives

$$
v_{\mathrm{b}}-v_{\mathrm{s}}=h\left(\overline{\dot{\epsilon}}_{x}+\overline{\dot{\epsilon}}_{z}\right)
$$

where $v_{\mathrm{s}}, v_{\mathrm{b}}$ are the vertical components of velocity at the surface and bed and $\dot{\epsilon}_{x}, \overline{\dot{\epsilon}}_{z}$ are strain-rates averaged over the ice thickness $h=h_{\mathrm{s}}-h_{\mathrm{b}}$.

If we assume that ice is neither formed nor melted at the glacier bed, there can be no flow normal to the bed. The condition for this is

$$
\mathrm{D} F_{\mathrm{b}} / \mathrm{D} t=\mathrm{o}
$$

where $\mathrm{D}$ denotes differentiation following the motion. In the present case, from Equation (3), if $u_{\mathrm{b}}, v_{\mathrm{b}}, w_{\mathrm{b}}$ denote the velocity components at the bed,

$$
\mathrm{D} F_{\mathrm{b}} / \mathrm{D} t=-u_{\mathrm{b}}\left(\partial h_{\mathrm{b}} / \partial x\right)+v_{\mathrm{b}}-w_{\mathrm{b}}\left(\partial h_{\mathrm{b}} / \partial z\right)=0 .
$$

Substitution in Equation (4) gives

$$
\dot{\epsilon}_{x}=h^{-1}\left[u_{\mathrm{b}}\left(\partial h_{\mathrm{b}} / \partial x\right)+w_{\mathrm{b}}\left(\partial h_{\mathrm{b}} / \partial z\right)-v_{\mathrm{s}}\right]-\overline{\dot{\epsilon}}_{z}
$$

For points on the center-line of the glacier, $w_{\mathrm{b}}=0$ and we have

$$
\overline{\dot{\epsilon}}_{x}=h^{-1}\left[u_{\mathrm{b}}\left(\partial h_{\mathrm{b}} / \partial x\right)-v_{\mathrm{s}}\right]-\bar{\epsilon}_{z} .
$$

Except for a change of coordinate system, this is the formula that Savage and Paterson ( 1963 ) used to calculate $\overline{\dot{\epsilon}}_{x}$.

When $\overline{\boldsymbol{\epsilon}}_{x}$ is known, we calculate $\left(\dot{\boldsymbol{\epsilon}}_{x}\right)_{\mathrm{b}}$ from the measured value of $\left(\dot{\boldsymbol{\epsilon}}_{x}\right)_{\mathrm{S}}$ by the formula

$$
\left(\dot{\epsilon}_{x}\right)_{\mathbf{b}}=2 \overline{\dot{\epsilon}}_{x}-\left(\dot{\epsilon}_{x}\right)_{\mathrm{s}} \text {. }
$$

This rests on the assumption of simple bending, namely that $\dot{\epsilon}_{x}$ varies linearly with depth. This is the simplest assumption that can be made: to assume a more complex relation seems hardly justified. This assumption was made previously in the analysis of bore-hole deformation (Paterson and Savage, I963[b]). It leads to a value of $0.0003 \mathrm{a}^{-1}$ for $\left(\dot{\epsilon}_{x}\right)_{\mathbf{b}}$ at hole 322 , which agrees satisfactorily with the observation of Raymond and Kamb (1968) that the strainrate "approaches zero toward the bottom" in this region.

In the calculations we have to assume that $\dot{\epsilon}_{z}$ does not vary with depth, so that in Equation (5) we can replace $\overline{\dot{\epsilon}}_{z}$ by $\left(\dot{\epsilon}_{z}\right)_{\mathrm{s}}$. As $\left(\dot{\epsilon}_{z}\right)_{\mathrm{s}}$ is small, this procedure is unlikely to introduce appreciable errors.

The calculations were carried out in a coordinate system in which the $x$-axis, instead of being horizontal, was parallel to the average bed of the glacier between the two stations. A separate coordinate system was used for each pair of stations. (In the following paragraph, 
quantities are measured in this coordinate system and $\partial h_{\mathrm{b}} / \partial x$ denotes the difference between the slope of the bed at the station and the average bed slope.)

The calculations were carried out as follows. At hole 322 , all quantities on the right-hand side of Equation (5) were measured. Thus $\overline{\dot{\epsilon}}_{x}$ was calculated from Equation (5) and then $\left(\dot{\epsilon}_{x}\right)_{\mathrm{b}}$ from Equation (6). We then use this value to calculate

$$
\Delta u_{\mathrm{b}}=\left(\dot{\boldsymbol{\epsilon}}_{x}\right)_{\mathrm{b}} \Delta x .
$$

Here $\Delta x$ is the distance between hole 322 and Li9 (the next seismic station down-glacier) and $\Delta u_{\mathrm{b}}$ is the correction to be added to the value of $u_{\mathrm{b}}$ at hole 322 to give a first approximation to $u_{\mathrm{b}}$ at Lig. (Use of a coordinate system parallel to the average bed eliminates a term in $\Delta y$ from Equation (7).) With this approximation, we then calculate $\left(\dot{\epsilon}_{x}\right)_{\mathrm{b}}$ at Lig by means of Equations (5) and (6). We then calculate a new value of $\Delta u_{\mathrm{b}}$ from Equation (7) using the average of the values of $\left(\dot{\epsilon}_{x}\right)_{\mathrm{b}}$ at hole 322 and Lig. This gives a second approximation to $u_{\mathrm{b}}$ at Lig. The process is repeated until there is no further change in the value of $u_{\mathrm{b}}$ at Lig. The final value of $\left(\dot{\epsilon}_{x}\right)_{\mathrm{b}}$ at Lig is then used in Equation (7) to give a first approximation to $u_{\mathrm{b}}$ at the next station.

I am indebted to Dr J. F. Nye for pointing out an alternative to the numerical solution namely, to solve the differential equation for $u_{\mathrm{b}}$ analytically. Equation (7) is equivalent to

where

$$
\mathrm{d} u_{\mathrm{b}} / \mathrm{d} x=g(x) u_{\mathrm{b}}+f(x)
$$

and

$$
g(x)=2 h^{-1} \mathrm{~d} h_{\mathrm{b}} / \mathrm{d} x
$$

$$
f(x)=-2 h^{-1} v_{\mathrm{s}}-\left(\dot{\boldsymbol{\epsilon}}_{x}\right)_{\mathrm{s}}-2 \overline{\dot{\epsilon}}_{z} \text {. }
$$

The solution is

$$
u_{\mathrm{b}}=\exp \left[\int g(x) \mathrm{d} x\right] \int f(x) \exp \left[-\int g(x) \mathrm{d} x\right] \mathrm{d} x .
$$

For the special case when the glacier bed is a plane, $g(x)=0$ and the solution reduces to

$$
u_{\mathrm{b}}=\int f(x) \mathrm{d} x \text {. }
$$

However, for the case of Athabasca Glacier, $f(x)$ and $g(x)$ cannot be represented by simple functions. The numerical solution has to be used.

The calculations were carried, through five intermediate seismic stations, to hole 209. The calculated value of $u_{\mathrm{b}}$ at hole 209 was $9.0 \mathrm{~m} \mathrm{a}^{-1}$. We consider that this is satisfactory agreement with the measured value of $6.5 \pm 3.5 \mathrm{~m} \mathrm{a}^{-1}$.

The sliding velocity was also calculated at four seismic stations up-glacier from hole 322 and three stations below hole 209. (The lowest station, $\mathrm{L}_{37}$, had to be excluded because the vertical velocity was not measured there). There is no check on these values however.

This method of calculating sliding velocity is based on the following assumptions:

(I) Ice is incompressible.

(2) There is no flow normal to the glacier bed.

(3) The longitudinal strain-rate varies linearly with depth.

(4) The transverse strain-rate does not vary with depth.

The method is not restricted to a glacier in a steady state nor to any particular flow law. Nor do we have to assume that the surface and bed are planes.

This is certainly not a precise method of calculating sliding velocity. The measurements of ice thickness, bed slope, velocity, and strain-rate are subject to experimental inaccuracies. And assumptions (3) and (4) will not be strictly true. Nevertheless we think that the calculated values should at least show the general trend of sliding velocity in this part of the glacier.

Table I lists, for each seismic station, the horizontal components of surface and sliding velocity, ice thickness, surface and bed slopes and basal shear stress. The bed slope given is 
that measured at each station, not the average slope between stations. The basal shear stress was calculated from Equation (2), with values of shape factor $F$ obtained from table IV of Nye (1965) on the assumption that the glacier has a parabolic cross-section.

Table I. Surface and sliding velocities, ICE thickness, SUrface and Bed slopes, and basal. SHEAR STRESS AT SEISMic STATIONS ON ATHABasca GLacier

\begin{tabular}{|c|c|c|c|c|c|c|}
\hline Station & $\begin{array}{c}u_{\mathrm{s}} \\
\mathrm{m} \mathrm{a}^{-1}\end{array}$ & $\mathrm{ma}^{u_{\mathrm{b}}}$ & $\begin{array}{l}h \\
\mathrm{~m}\end{array}$ & $\stackrel{\alpha}{\operatorname{deg}}$ & $\underset{\text { deg }}{\beta}$ & $\begin{array}{c}\tau \\
\text { bar }\end{array}$ \\
\hline $\mathrm{L}_{10.5}$ & 70.1 & 26 & 312 & 4.0 & 16.5 & 1.1 \\
\hline $\mathrm{LI}_{2}$ & $59 \cdot 3$ & 29 & 323 & 2.8 & -1.2 & 0.8 \\
\hline $\mathrm{L}_{4}$ & $5^{1} \cdot 9$ & $3^{2}$ & 317 & 3.2 & -1.8 & 1.0 \\
\hline $\mathrm{L}_{1} 6$ & 46.5 & 31 & 322 & 4.1 & 3.1 & $1 \cdot 3$ \\
\hline Hole 322 & 38.9 & 30 & 322 & $3 \cdot 5$ & 5.6 & I. I \\
\hline $\mathrm{L}_{19}$ & 37.5 & 30 & 310 & $3 . \mathrm{I}$ & 3.1 & 0.9 \\
\hline $\mathrm{L}_{21}$ & $34 \cdot 4$ & 28 & 310 & 1.7 & -2.8 & 0.5 \\
\hline $\mathrm{L}_{23}$ & 33.4 & 28 & 273 & 2.8 & -4.2 & $0 . \overline{8}$ \\
\hline L.25 & 33.2 & 22 & 248 & 3.8 & 5.8 & 1.0 \\
\hline L.27 & 32.5 & 14 & 248 & 5.5 & 11.5 & 1.4 \\
\hline Hole 209 & 28.8 & 6.5 & 209 & 6.3 & I6.9 & I. 4 \\
\hline $\mathrm{L}_{30.5}$ & 27.8 & 12 & 167 & 5.2 & I. I & I.0 \\
\hline $\mathrm{L}_{32}$ & 26.1 & 9 & 118 & 5.0 & 6.0 & 0.7 \\
\hline $\mathrm{L}_{34}$ & 26.5 & o & 113 & 8.8 & I 1.8 & I. 3 \\
\hline
\end{tabular}

\section{Discussion of Results}

Theoretical studies of glacier sliding have yielded relations between sliding velocity, basal shear stress, and other parameters. For lack of data, however, these relations have not been adequately tested. Perhaps the most widely used relation is that of Weertman ( $1957, \mathrm{I} 964[\mathrm{~b}])$ :

$$
u_{\mathrm{b}}=B S^{p} \tau^{m} \text {. }
$$

Here $u_{\mathrm{b}}$ is sliding velocity, $\tau$ basal shear stress, $S$ measures the smoothness of the glacier bed (the larger $S$, the less rough the bed) and $B, m$ and $p$ are constants. The value of $m$ is about 2, that of $p$ about 4. A major difficulty in trying to verify this relation is that $u_{\mathrm{b}}$ depends on a high power of $S$, a quantity that is very difficult to measure.

Meier ( 1968 ) has recently examined the relation between $u_{\mathrm{b}}$ and $\tau$ for Nisqually Glacier. He used Equation (I) to calculate $u_{\mathrm{b}}$ from measurements of $u_{\mathrm{s}}$, estimates of $h$, and values of $\tau$ calculated from Equation (2). The need to determine $S$ was eliminated by confining the analysis to one point on the glacier bed. A range of velocities was obtained because the values of $u_{\mathrm{s}}, h$ and $\tau$ changed by large amounts during the 22 year period of observation. Meier concluded that $u_{\mathrm{b}}$ was not a simple, single-valued function of $\tau$.

The fact that $S$ is unknown presents a major obstacle to using the Athabasca Glacier data to test Equation (8). If we assume, as in some theoretical studies, that $S$ has the same value at all points on the glacier bed, we would expect the data to show a relation between $u_{\mathrm{b}}$ and $\tau$. However, the measured sliding velocity at hole 322 is nearly five times that at hole 209, though the value of $\tau$ is slightly smaller (I.I bar against I.4 bar). Again, regression analysis of the data in Table I showed no significant relation between $u_{\mathrm{b}}$ and $\tau$. (On the other hand, a significant relation was found between sliding velocity and ice thickness.) Thus one or more of the following statements must be true:

I. The roughness of the glacier bed is not uniform.

2. The basal shear stress cannot be calculated by Equation (2).

3. The data do not fit Equation (8).

The assumption of uniform roughess is unlikely to be correct. As Figure I shows, the glacier bed appears to be much rougher down glacier from station L27 than it is above that point. And sliding velocities below $\mathrm{L}_{27} 7$ are much smaller than they are above, as Equation (8) predicts. However, the scale of measurement of $S$ must be considered. On Weertman's 
theory, the sliding velocity is mainly controlled by obstacles of a certain size on the glacier bed. The critical size is a matter of controversy (Kamb and LaChapelle, I964; Weertman, I964[a], [b]); however, it is probably in the range I $\mathrm{mm}$ to I $\mathrm{m}$. Presumably $S$ should be measured at this scale. On Weertman's theory, $S$ is assumed to have the same value for obstacles of all sizes; but this is unlikely to be true in a real glacier. Thus the roughness shown in Figure I, which has a scale of $100 \mathrm{~m}$, should not be used as an indication of the small-scale roughness. To obtain information on this will not be easy; radar sounding, at least at the wave-lengths used at present $(0.7 \mathrm{~m}$ to $10 \mathrm{~m})$, will not provide the answer.

There are two possible sources of inaccuracy in values of basal shear stress calculated from Equation (2): inaccuracies in allowing for the effect of the shape of the glacier channel, and neglect of the effect of variations in longitudinal stress along the glacier. Use of the shape factor appears to be the best method available for allowing for the effect of the channel. The method is only approximate, however, and it is difficult to estimate the amount by which the calculated value may differ from the actual shear stress.*

Lliboutry (1958) has shown that, when the longitudinal stress varies along the glacier, a correction term should be added to Equation (2). Collins (1968) has derived the formula rigorously and made clear the assumptions on which a calculation of the correction term must be based. These assumptions are:

(I) The slope of the bed is small.

(2) The shear strain-rate $\overline{\dot{\epsilon}}_{x y}$ is small compared with the direct strain-rates $\dot{\epsilon}_{x}, \dot{\epsilon}_{y}$, where bars denote average values over the ice thickness. (Collins assumed that all strains involving $z$ are zero.)

(3) $\dot{\epsilon}_{x}$ does not vary with depth.

The slope of the bed of Athabasca Glacier, in the area in question, reaches $17^{\circ}$. We know that the third assumption does not hold. The second assumption can be tested at the bore holes, where all the strain-rates have been measured. At hole $322, \overline{\dot{\epsilon}}_{x y}$ is $-0.012 \mathrm{a}^{-1}$ and $\overline{\hat{\epsilon}}_{x}$ is $-0.01 \mathrm{I} \mathrm{a}^{-1}$. At hole 209, $\overline{\dot{\epsilon}}_{x y}$ is $-0.049 \mathrm{a}^{-1}$ and $\bar{\epsilon}_{x}$ is $-0.003 \mathrm{a}^{-1}$. Thus the second assumption also breaks down. We are therefore unable to calculate Collins' correction term. Lliboutry (1968, equation (54)) has also derived a correction term to the equation for the shear stress. However the correction includes a term involving $\partial \sigma_{x} / \partial x$ integrated over the ice thickness, where $\sigma_{x}$ denotes longitudinal stress. It does not appear possible to evaluate this term.

For comparison with results from Athabasca Glacier, Table II lists all published measurements (as distinct from estimates) of sliding velocity known to us. (Haefeli (r95I) made observations in a tunnel in Glacier du Mt Collon. However, the tunnel reached the glacier bed at a point where the ice descended over a vertical cliff, $60 \mathrm{~m}$ high, and was separated from the rock by a gap of 2 to $4 \mathrm{~m}$. We do not consider that the ice velocity can be regarded as a sliding velocity. Theakstone $(1967)$ has measured basal sliding in a natural tunnel near the edge of Østerdalsisen, but he does not state the ice thickness or surface slope.) In some cases the data were insufficient for calculation of a shape factor, so all shear stresses were calculated without it. Thus the values of $\tau$ are not very reliable, particularly in the cases of Vesl-Skautbreen, a small steep corrie glacier, and Blue Glacier, where the measurements were made near the side of the glacier in an ice fall. In the Blue Glacier tunnel, the smoothness of the glacier bed was measured and Weertman ( $1964[\mathrm{~b}]$ ) showed that the sliding velocity was in reasonable agreement with the value calculated from Equation (8).

Regression analyses of the data in Table II gave results similar to those from Athabasca Glacier: no significant relation between sliding velocity and basal shear stress, but a significant

\footnotetext{
* A referee has pointed out that the lowest value of shear stress, 0.5 bar at L 21 , is found in an overdeepened area, where the subglacial channels are probably under hydrostatic pressure, a fact which is consistent with Lliboutry's theory of sliding.
} 
relation between sliding velocity and ice thickness. These data thus lend no support to Equation (8). As in the case of the Athabasca Glacier data however, the discrepancy could be accounted for by variations in roughness of the glacier bed, inaccuracies in calculated values of shear stress, or both.

Table II. Published mensurements of sliding velocity, ice thickness, surface slope and BASAL SHEAR STRESS

\begin{tabular}{|c|c|c|c|c|c|c|}
\hline Glacier & $\begin{array}{c}u_{\mathrm{s}} \\
\mathrm{m} \mathrm{a}^{-1}\end{array}$ & $\mathrm{~m} \mathrm{a}^{u_{\mathrm{b}}}$ & $\begin{array}{l}h \\
\mathrm{~m}\end{array}$ & $\begin{array}{c}\alpha \\
\operatorname{deg}\end{array}$ & $\stackrel{\tau}{\text { bar }^{2}}$ & Reference \\
\hline Vesl-Skautbreen & 2.6 & 2.3 & $5^{\circ}$ & 25 & I.9 & McCall (1952) \\
\hline Tuyuksu & 4.2 & 2.8 & $5^{2}$ & 9 & 0.7 & Vilesov ( $196 \mathrm{I}$ ) \\
\hline Blue & 6.6 & 5.8 & 26 & 28 & 0.7 & Kamb and LaChapelle (1964) \\
\hline Athabasca & 28.8 & 6.5 & 209 & 6.3 & 2.0 & Savage and Paterson (1963) \\
\hline Aletsch & 35 & 17.5 & 137 & 4.0 & 0.8 & Gerrard and others (1952) \\
\hline Athabasca & 38.9 & 30 & 322 & $3 \cdot 5$ & 1.75 & Savage and Paterson (1963) \\
\hline Salmon & 78 & 34 & $49^{\circ}$ & 2.0 & 1.4 & Mathews (1959) \\
\hline
\end{tabular}

For the combined data in Tables I and II, the regression of sliding velocity on ice thickness is

$$
u_{\mathrm{b}}=0.1 \mathrm{I} h^{0.95}
$$

with $h$ in meters and $u_{\mathrm{b}}$ in $\mathrm{m} \mathrm{a}^{-1}$. Figure 2 shows this relation and the observations. This relation is presented merely as an empirical fit to the data. We do not suggest that it implies any causal relation between ice thickness and sliding velocity. Nor do we suggest that an equation of this form has any wide application. In fact, we can see, by considering the situation in an ice fall, that such a relation cannot be true everywhere. The ice is relatively thin in an ice fall; yet velocities are high and sliding probably accounts for a large part of the total motion. Moreover, $u_{\mathrm{b}}$ must be related to other factors as well as $h$, otherwise the direction of sliding would be undetermined.

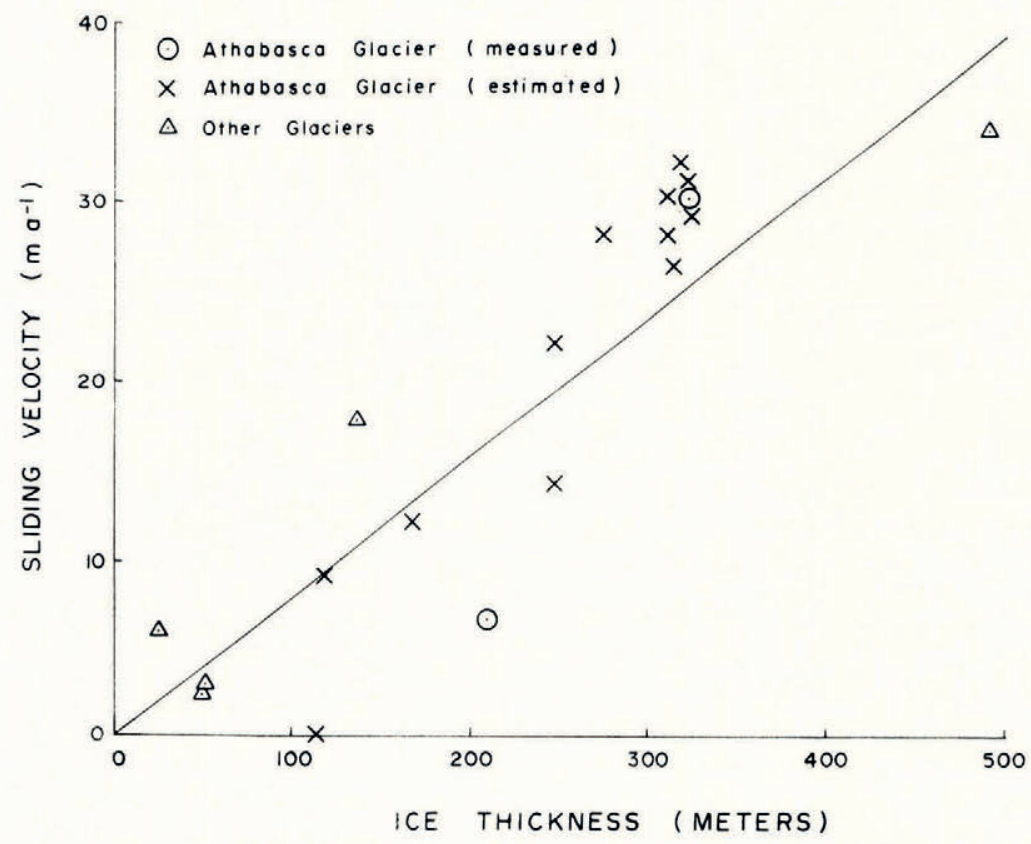

Fig. 2. Relation between sliding velocity and ice thickness. The line represents Equation (9). 


\section{Acknowledgements}

I should like to thank Drs J. F. Nye and J. Weertman for valuable comments on a draft of this paper.

\section{MS. received 17 June 1969}

\section{REFERENCES}

Collins, I. F. 1968. On the use of the equilibrium equations and flow law in relating the surface and bed topography of glaciers and ice sheets. Fournal of Glaciology, Vol. 7, No. 50, p. 199-204.

Gerrard, J. A. F., and others. 1952. Measurement of the velocity distribution along a vertical line through a glacier, by J. A. F. Gerrard, M. F. Perutz and A. Roch. Proceedings of the Royal Society, Ser. A, Vol. 213. No. 1115 , p. $546-58$.

Haefeli, R. I951. Some observations on glacier flow. Journal of Glaciology, Vol. 1, No. 9, p. 496-500.

Kamb, W. B., and LaChapelle, E. R. 1964 . Direct observation of the mechanism of glacier sliding over bedrock. Journal of Glaciology, Vol. 5, No. 38, p. $159-72$.

Lliboutry, L. 1958. La dynamique de la Mer de Glace et la vague de 1891-95 d'après les mesures de Joseph Vallot. Union Géodésique et Géophysique Internationale. Association Internationale d'Hydrologie Scientifique. Symposium de Chamonix, $16-24$ sept. 1958 , p. 125-38.

Lliboutry, L. 1968 . General theory of subglacial cavitation and sliding of temperate glaciers. Journal of Glaciolog', Vol. 7 , No. 49 , p. $21-58$.

McCall, J. G. 1952. The internal structure of a cirque glacier: report on studies of the englacial movements and temperatures. Fournal of Glaciology, Vol. 2, No. 12, p. 122-31.

Mathews, W. H. 1959. Vertical distribution of velocity in Salmon Glacier, British Columbia. Journal of Glaciolog), Vol. 3, No. 26, p. $448-54$.

Meier, M. F. I968. Calculations of slip of Nisqually Glacier on its bed: no simple relation of sliding velocity to shear stress. Union de Géodésie et Géophysique Internationale. Association Internationale d'Hydrologie Scientifique. Assemblée générale de Berne, 25 sept.-7 oct. 1967. [Commission de Neiges et Glaces.] Rapports et discussions, p. 49-57.

Nye, J. F. 1952. The mechanics of glacier flow. Fournal of Glaciology, Vol. 2, No. 1 2, p. 82-93.

Nye, J. F. 1965. The flow of a glacier in a channel of rectangular, elliptic or parabolic cross-section. Fournal of Glaciology, Vol. 5, No. 41, p. 661-9o.

Paterson, W. S. B. Unpublished. Observations on Athabasca Glacier and their relation to the theory of glacier flow. [Ph.D. thesis, University of British Columbia, Vancouver, B.C., 1962.]

Paterson, W. S. B., and Savage, J. C. 1963[a]. Geometry and movement of the Athabasca Glacier. Fournal of Geophysical Research, Vol. 68, No. 15, p. 4513-20.

Paterson, W. S. B., and Savage, J. C. $1963[\mathrm{~b}]$. Measurements on Athabasca Glacier relating to the flow law of ice. Journal of Geophysical Research, Vol. 68, No. 1 5, p. 4537-43.

Raymond, C. F., and Kamb, W. B. 1968. Internal deformation over a transverse section of a valley glacier. Transactions. American Geophysical Union, Vol. 49, No. I, p. 31 3. [Abstract.]

Savage, J. C., and Paterson, W. S. B. 1963. Borehole measurements in the Athabasca Glacier. Fournal of Geophysical Research, Vol. 68, No. ${ }_{15}$, p. $452 \mathrm{I}-36$.

Theakstone, W. H. 1967 . Basal sliding and movement near the margin of the glacier Østerdalsisen, Norway. Journal of Glaciology, Vol. 6, No. 48, p. 805-16.

Vilesov, E. N. 196r. Temperature of ice in the lower parts of the Tuyuksu glaciers. Union Géodésique et Géophysique Internationale. Association Internationale d'Hydrologie Scientifique. Assemblée générale de Helsinki, 25-7-6-8 1960. Commission des Neiges et Glaces, p. 31 $3^{-24}$.

Weertman, J. 1957. On the sliding of glaciers. Journal of Glaciology, Vol. 3, No. 21, p. 33-38.

Weertman, J. I $1964[\mathrm{a}]$. Discussion on Kamb and LaChapelle's paper "Direct observation of the mechanism of glacier sliding over bedrock". Fournal of Glaciology, Vol. 5, No. 39, p. 374-75. [Letter.]

Weertman, J. I964[b]. The theory of glacier sliding. fournal of Glaciology, Vol. 5, No. 39, p. 287-303. 